\title{
Identification and Characterization of Chitinase Enzyme Producing Bacteria from Bat Guano and its Potential to Inhibit the Growth of Fungus Colletotrichum Sp. Cause Anthracnose on the Chili by In Vitro
}

\author{
Heny Rahmawati ${ }^{1}$, Andi Joko Purnomo ${ }^{1}$, Siti Umniyatie ${ }^{1}$, Drajat Pramiadi ${ }^{1}$ and Noorkomala sari ${ }^{2}$
}

\begin{abstract}
This study aims to determine the chitinase enzyme producing bacteria with high enzyme activity, selected genus bacteria, chitinase enzyme activity selected bacteria and determine the effect of bacteria in suppressing the growth of fungus Colletotrichum sp. Bacteria isolated from the guano of Grodo Cave Gunung Kidul regency, Yogyakarta with pour plate method and screening against isolates that have the greatest chitinase enzyme activity. Selected bacterial isolates were characterized and identified using the profile matching. The bacteria were then tested in suppressing the growth of fungus Colletotrichum sp. Using modified Kirby Bauer method. Antagonist test results were analyzed using analysis of variance with SPSS version 22.0. Acquired 7 isolates of the bacteria producing the enzyme chitinase with two selected isolates that isolates 26 which has the enzyme activity of 1.13 units / $\mathrm{ml}$ and isolates 31 which has the enzyme activity 0.98 units / $\mathrm{ml}$. The identification results showed isolates 26 suspected a Streptomyces genus with similarity percentage of $84.61 \%$ and isolates 31 is a Morococcus genus with similarity percentage of $73.08 \%$. Antagonist test results show both isolates significant effect in inhibiting the growth of fungus Colletotrichum $\mathrm{sp}$. with a significance value $(\mathrm{p} \leq$ 0.05 ). Further test DMRT, showed isolates 26 has a greater effect in inhibiting the fungus Colletotrichum sp. compared to isolates 31.
\end{abstract}

Keywords - Chitinase Enzyme Producing Bacteria, Guano, Colletotrichum sp., Anthracnose.

\section{INTRODUCTION}

Chitinase enzyme producing bacteria is a bacteria that produces the chitinase enzyme to chitin assimilation as a source of carbon and nitrogen [1]. Chitinase enzyme producing bacteria obtained from sources that contain chitin like the exoskeletons of crustaceans, sea water and marine sediments [2]. Another source of chitin for example is guano (bat droppings). Recent research by [3] showed guano from insectivorous bats, Rhinolophus and Hipposideros containing $28 \%$ chitin.

Diversity of microorganisms in guano supported by the high temperature and high humidity of guano $(96.5 \%$ to

\footnotetext{
${ }^{1}$ Department of Biology Education, Faculty of Mathematics and Science, Yogyakarta State University

${ }^{2}$ Departmen of Biology, Faculty Biology, Gadjah Mada University,
}

99.8\%) where that condition can interact with components of guano and provide nutrients for microorganisms reproduction and create an excellent habitat for microorganisms [2].

Anthracnose is the main disease that causes low productivity of chili in Indonesia [4]. The disease is caused by the fungus Colletotrichum sp. which cause damage to fruit and loss most of harvest result. Until now the use of synthetic funguscides is still a mainstay of measures to reduce losses and yield losses due to rot anthracnose disease [5]. Intensive use of funguscides provide a lot of negative effects, such as pathogen resistance to funguscides, and left the chemical residues on agricultural products [6]. Chitinolytic bacteria can degrade chitin of fungal cell wall so that the bacteria are very potential to inhibit the growth of pathogenic fungus on plants [7].

Based from that facts above, this study was conducted to determine the character of the chitinase enzyme producing bacteria which have high enzyme activity on the bat guano and its potential as an antifungal for Colletotrichum sp. tested in vitro

\section{RESEARCH METHODS}

\section{A. Isolation and Purification Bacteria from Bat Guano}

Guano samples diluted with dilution factor 10-4 to 10-8 then grown on Nutrient Agar (NA) media using pour plate method. Purification bacteria were performed by the quadrant streak method and moved within NA slant medium in a test tube.

\section{B. Isolate Screening of Chitinase Enzyme Producing} Bacteria

Two loops of bacterial isolates were inoculated into $20 \mathrm{ml}$ Nutrient Broth (NB) medium containing $0.5 \%$ colloidal chitin. Samples were incubated on a shaker at $37^{\circ} \mathrm{C}$ and $100 \mathrm{rpm}$ for 24 hours. Isolates were centrifuged at a speed of 4,000 rpm (30 minutes) to obtain the chitinase enzyme crude extract in the supernatant.

$\mathrm{N}$-acetylglucosamine (GlnAc) product measured by as much as $0.15 \mathrm{ml}$ of crude enzyme (cell-free supernatant) was added to a mixture of $0.15 \mathrm{ml}$ substrate chitin $1 \%$ and $0.3 \mathrm{ml}$ of $\mathrm{pH} 7$ buffer solution. The mixture was homogenized and 
incubated at temperature of $37^{\circ} \mathrm{C}$ for 60 minutes and then heated at $100^{\circ} \mathrm{C}$ for 3 minutes.

Control solution made by adding $0.15 \mathrm{ml}$ of crude enzyme after heated at $100^{\circ} \mathrm{C}$ for 3 minutes. The solution was then centrifuged at $3000 \mathrm{rpm}$ for 20 minutes. The number of $\mathrm{N}$ acetylglucosamine is determined by mixing $0.5 \mathrm{ml}$ of the supernatant with $0.5 \mathrm{ml}$ of distilled water and $1 \mathrm{ml}$ Schale reagent. The absorbance of the solution is measured at a wavelength of $420 \mathrm{~nm}$. The concentration of $\mathrm{N}$ acetylglucosamine was measured by a standard curve of $\mathrm{N}$ acetylglucosamine.

Chitinolytic enzyme activity value is calculated using the formula [8]:

Enzyme Activity $(\mathrm{U} / \mathrm{ml})=\frac{[[s]-[c]] x d f}{M W x t x W e}$

With:

Df: dilution factor

substrate ug / $\mathrm{ml}$

[S]: [GlnNAc] on the

Ve: crude enzyme volume (ml)

the control ug / ml

t: optimum temperature incubation time (minutes)

MW: GlnNAc molecular weight (221.2)

Measuring the enzyme activity of the isolates were selected based on the phase of bacterial life. Measurement of the enzyme is done on the lag phase, log, and stationary with each 2 repetitions

\section{Preparation of Bacterial Growth Standard Curve}

One ose of bacteria was inoculated on Nutrient Broth (NB) media and incubated shaker for 24 hours at a speed of $100 \mathrm{rpm}$ as activation I. $10 \%$ of bacteria in the activation I inoculated into the new NB media as activation II. The bacteria were then incubated shaker for 24 hours at a speed of $100 \mathrm{rpm}$. The growth curve of bacteria was measured by transferring $10 \%$ activation II into new NB media. The density of cells then measured using spectrophotometric method with a wavelength of $540 \mathrm{~nm}$, the measurement is done every two hours, starting at 0 hour until 48th hours.

\section{D. solate Characterization of Chitinase Enzyme Producing} Bacteria

Characterization of bacterial colonies performed on selected isolates and characterized based on observation of macroscopic, microscopic and biochemical. Macroscopic observation includes colony color, colony edge, colony elevation, and colony form. Microscopic observation include cell shape and arrangement of the cells using Gram's staining and spores staining. Biochemical test include carbohydrate fermentation, gelatin hydrolysis, nitrate reduction, H2S production, blood agar, hydrolysis of starch, production of urease, nitrogen fixation, growth in the variation of $\mathrm{NaCl}, \mathrm{pH}$, and temperature.

TABLE I. MEASUREMENT RESULT OF GRODO CAVES CLIMATIC FACTORS

\begin{tabular}{|l|l|l|l|l|l|l|l|}
\hline No & Point & $\begin{array}{c}\text { Air Temperature } \\
\left(\mathbf{(}^{\mathbf{0}} \mathbf{C}\right)\end{array}$ & $\begin{array}{c}\text { Air } \\
\text { Humidity } \\
\mathbf{( \% )}\end{array}$ & $\begin{array}{c}\text { Soil } \\
\text { Temperatur } \\
\mathbf{e}\left(\mathbf{(}^{\mathbf{0}} \mathbf{C}\right)\end{array}$ & $\begin{array}{c}\text { Soil Humidity } \\
\mathbf{( \% )}\end{array}$ & $\begin{array}{c}\text { Soil } \\
\mathbf{p H}\end{array}$ & $\begin{array}{c}\text { Light Intencity } \\
\text { (lux) }\end{array}$ \\
\hline 1 & Point I & 35 & 78 & 25 & 37,5 & 6 & 0 \\
\hline 2 & Ponit II & 32 & 86 & 25 & 52 & 5,5 & 0 \\
\hline 3 & Point III & 33,5 & 82 & 24 & 50 & 5,6 & 0 \\
\hline
\end{tabular}

\section{E. Identification of Selected Chitinase Enzyme Producing Bacteria}

Identification of the bacteria using profile matching method based on Bergey's Manual of Determinative Bacteriology 9th Edition compared to genus.reference.

\section{F. Test of Antagonistic Bacteria against Colletotrichum sp.}

The method used in this test is a modification KirbyBauer method by inoculating the cultured of Colletotrichum sp. into PDA (Potato Dextrose Agar) medium using point streak technique and incubating at room temperature for 72 hours. Bacterial isolates with a cell density reached 1 , then centrifuged at a speed of 10,000 rpm for 15 minutes to obtain a crude enzyme. Submerge the paper disc on $3 \mathrm{ml}$ bacterial supernatant for 15 minutes. Laid paper disc later on the side of PDA that has been inoculated culture Colletotrichum sp. the sample then incubated at room temperature for 24 hours. Mold growth inhibition zone indicated by the formation of a clear zone around the paper disc. Measure the diameter of clear zone to determine the magnitude of inhibition of bacteria against fungus.

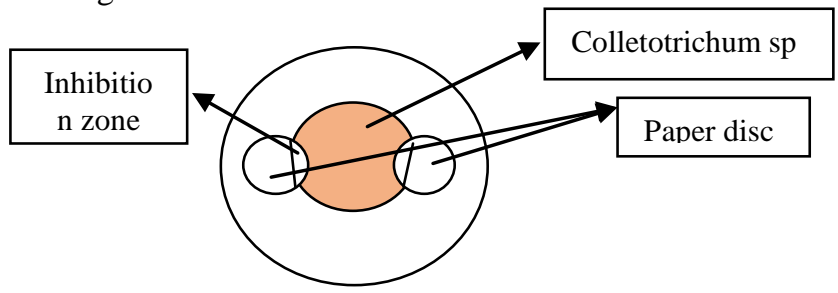

\section{G. Data Analysis Technique}

Analysis of the antagonist test variant performed using SPSS (Statistical Product and Service Soluition) version 22.0 using one way ANOVA (analysis of variants) technique. If the test results show significant results then followed by a further test, namely DMRT (Duncan Multiple Range Test).

\section{A. Environmental Conditions and Microclimates of Grodo Caves}

Grodo caves are karst caves located in the Sawahan Village, Playen District, Gunung Kidul Regency, Yogyakarta. The cave is located at the point 7.91585 latitude and 110.73913 longitude. Grodo Caves climatic conditions measured on 3 points at the sampling locations of bat guano. All of the data sampling point is dark zone's cave. The measurement results of climatic factors can be seen in Table 1 .

\section{RESUlt AND DisCUSSION}


Environmental conditions in this cave support a variety life of living creatures such as bats, swiftlets, crickets, spiders, ants, centipedes, and microorganisms such as collembolla, fungus, and bacteria.

\section{B. Isolation of Bat Guano Bacteria}

Isolation of bacteria were performed using a pour plate method with serial dilutions of 10-7 to $10-8$ and repeat twice. the density of bacteria calculated based on the Total Plate Count. The results of bacterial isolation can be seen in Table 2 .

TABLE II. RESULTS OF ISOLATION AND COUNTING BAT GUANO BACTERIA

\begin{tabular}{|c|c|c|}
\hline \multirow{2}{*}{ Dilutions } & \multicolumn{2}{|c|}{ Repetition } \\
\hline & I & II \\
\hline $10^{-4}$ & $>300$ & $>300$ \\
\hline $10^{-5}$ & 86 & 73 \\
\hline $10^{-6}$ & 56 & 62 \\
\hline $10^{-7}$ & 53 & 24 \\
\hline $10^{-8}$ & 47 & 21 \\
\hline
\end{tabular}

The number of bacteria on bat guano based on Table 2 were calculated using the formula is $3,347 \times 10^{7} \mathrm{cfu} / \mathrm{g}$.

Microorganism diversity in guano fueled by the condition of the guano that has a high temperature and high humidity (96.5\% to $99.8 \%$ ) where that condition can interact with components of guano and provide nutrients for microorganisms reproduction and create a habitat for microorganisms [9].

\section{Screening of Chitinase Enzyme Producing Bacteria}

Screening bacteria resulted 7 positive isolates that produce chitinase enzyme which is isolates $6,8,26,31,32,33$, and 34 . Isolate 26 and 31 have the highest chitinase enzyme activity $(1.13 \mathrm{U} / \mathrm{ml}$ and $0.98 \mathrm{u} / \mathrm{ml})$, so that these isolates are two isolates were selected for identification and testing for antagonistic activity against fungus Colletotrichum sp.

The existence of chitin in insect-eating bat guano should trigger microorganisms using chitin as a source of nutrition that makes the bat guano as a habitat for breaking chitin microorganisms. Environment containing many chitin, there will be a chances for chitinase-producing microorganisms to life[10].

Research by [11] isolated the chitinase enzyme producing bacteria of the intestinal insectivorous bats that resulted in the discovery of bacteria in symbiosis with the bat to hydrolize chitin of insects consumed by bats. The existence of the chitinase enzyme producing bacteria in the intestine of bats is possible for the source of the chitinase enzyme producing bacteria in bat guano.

\section{The Growth Curve of Selected Isolates chitinase enzyme} Producing Bacterial

Growth curves of isolates 26 and 31 are used to determine the activity of chitinase bacteria according to life phase. The growth curve of bacteria can be seen in Figures 1 and 2 .

Figure 1 shows the growth curve of isolates 26 which has a phase lag on the 0 up to $2^{\text {nd }}$ hours, the exponential phase occurs beginning at the $2^{\text {nd }}$ hour and end at $26^{\text {th }}$ hour and further bacteria begin to enter the stationary phase until $48^{\text {th }}$ hours.

Figure 2 shows the growth curve isolates 31 . Isolate 31 has a phase lag on 0 to $2^{\text {nd }}$ hour and subsequently entered a phase of exponential in the $2^{\text {nd }}$ hour to $30^{\text {th }}$ hour. Furthermore, the bacteria enter the stationary phase on the $30^{\text {th }}$ hour until $48^{\text {th }}$ hours.

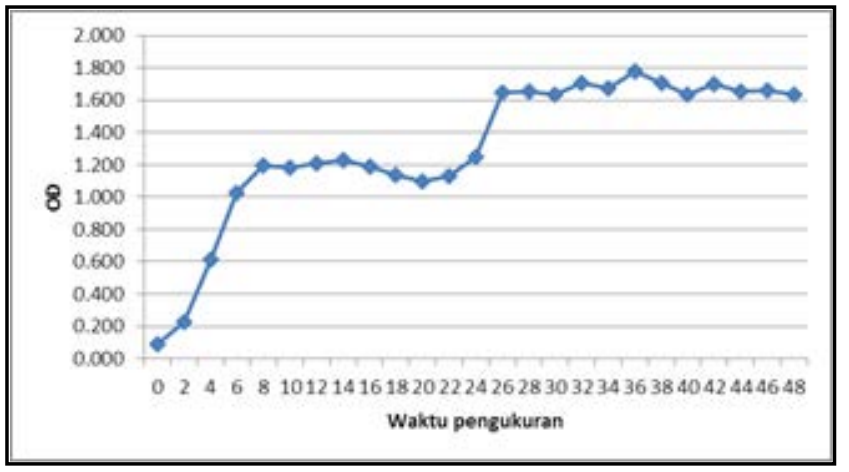

Fig. 1. Graph of the growth curve isolates 26

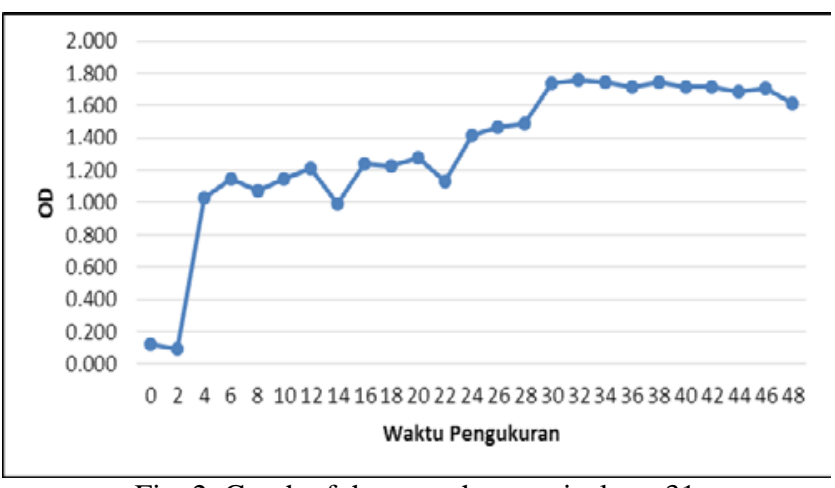

Fig. 2. Graph of the growth curve isolates 31

\section{E. Chitinase Enzyme activity of Selected Bacteria}

Chitinase enzyme activity measurements performed following the growth phase of bacteria start from 0 hours, the exponential phase and the stationary phase.

TABLE III. CHITINASE ENZYME ACTIVITY OF ISOLATES 26 AND 31

\begin{tabular}{|c|c|c|c|c|c|}
\hline \multirow{2}{*}{${ }_{0}^{\mathrm{N}}$} & \multirow{2}{*}{$\begin{array}{l}\text { Isol } \\
\text { ate }\end{array}$} & \multirow{2}{*}{$\begin{array}{l}\text { Growt } \\
\text { h phase }\end{array}$} & \multicolumn{2}{|c|}{ [GlnNac] $(\mu \mathrm{g} / \mathrm{ml})$} & \multirow{2}{*}{$\begin{array}{l}\text { Chitinase } \\
\text { activity } \\
\text { (u/ml) }\end{array}$} \\
\hline & & & S & $\mathbf{K}$ & \\
\hline \multirow{3}{*}{1} & \multirow{3}{*}{26} & 0 & - & - & - \\
\hline & & $\begin{array}{l}\text { Ekspo } \\
\text { nential }\end{array}$ & 4103,80 & 3952,92 & 0,30 \\
\hline & & $\begin{array}{l}\text { Statio } \\
\text { ner }\end{array}$ & 4168,09 & 3441,24 & 1,46 \\
\hline \multirow{3}{*}{2} & \multirow{3}{*}{31} & 0 & - & - & - \\
\hline & & $\begin{array}{l}\text { Ekspo } \\
\text { nential }\end{array}$ & 3985,72 & $0^{3907,0}$ & 0,16 \\
\hline & & $\begin{array}{l}\text { Statio } \\
\text { ner }\end{array}$ & 3677,40 & $0^{3447,8}$ & 0,46 \\
\hline
\end{tabular}

Measurements of chitinase enzyme activity performed in the growth phase start from 0 hours, the exponential phase and the stationary phase. Both isolates 26 and 31, on the hour of 0 , chitinase enzyme activity cannot measured, it can be seen from the production of $\mathrm{N}$-acetyl glucosamine which is not measured on a spectrophotometer. The absence of chitinase enzyme activity in the early stages of growth is because the bacteria is still in the process of adapting to the growth medium.

In the exponential phase, chitinase enzyme activity of isolates 26 is 0.30 units / $\mathrm{ml}$ and isolates 31 is 0.16 units / $\mathrm{ml}$. 
In the stationary phase, the chitinase enzyme activity of isolates 26 is 1.46 units / $\mathrm{ml}$ and isolates 31 is 0.46 units / $\mathrm{ml}$. The results showed that both isolates 26 and 31 had the highest enzyme activity in the stationary phase and the lowest at 0 hours.

The phase required by the microorganisms to start producing the enzyme chitinase is the exponential phase, which vary depending on each microorganisms. At this exponential phase of bacteria will replicate themselves led to a lots growing number. In this self-replicating process, it takes a large amount of energy that the bacteria will begin producing the enzyme chitinase which will be used to break down chitin substrate into the monomer and used as a source of carbon and nitrogen for the needs of the cell [10].

The results of the measurements indicates a discrepancy with the theory, where the stationary phase of the bacteria have an enzyme activity that is greater than exponential phase. This discrepancy maybe due to the delay measurement of enzyme activity in the exponential phase. The delay of this measurement, the possible causes of enzyme activity measured in exponential phase is lower than the stationary phase.

\section{F. Characterization and Identification of Selected Bacterial} Isolates

Identification is done by using the Profile Matching traced through characterization based on the book Bergey's Manual of Determinative Bacteriology 9th Edition then compared with a reference genus. The results of the identification can be seen in Table 4 and 5.

\begin{tabular}{|c|c|c|c|c|}
\hline No & \multicolumn{2}{|c|}{ Parameters } & $\begin{array}{c}\text { Genus } \\
\text { Reference } \\
\text { (Streptomyces) }\end{array}$ & $\begin{array}{l}\text { Isolate } \\
26\end{array}$ \\
\hline 1 & \multicolumn{2}{|l|}{ Colony edge } & Smooth & Smooth \\
\hline 2 & \multicolumn{2}{|c|}{ Gram staining } & + & + \\
\hline 3 & \multicolumn{2}{|l|}{ Cell form } & Coccus & Coccus \\
\hline 4 & \multicolumn{2}{|l|}{ Needs of $\mathrm{O}_{2}$} & Aerob & Aerob \\
\hline 5 & \multicolumn{2}{|c|}{ Katalase activity } & + & + \\
\hline 6 & \multicolumn{2}{|c|}{$\begin{array}{l}\text { Production of acid from } \\
\text { glucose }\end{array}$} & + & - \\
\hline 7 & \multicolumn{2}{|c|}{ Gelatin hydrolysis } & d & - \\
\hline 8 & \multicolumn{2}{|c|}{ Nitrate reduction } & $\mathrm{d}$ & - \\
\hline 9 & \multirow{2}{*}{$\begin{array}{l}\text { Optimum } \\
\text { growth } \\
\text { temperature } \\
\end{array}$} & $25^{\circ} \mathrm{C}$ & + & + \\
\hline 10 & & $37^{\circ} \mathrm{C}$ & + & + \\
\hline 11 & \multicolumn{2}{|c|}{ Dissolved pigment } & + & - \\
\hline 12 & \multicolumn{2}{|c|}{ Starch hydrolysis } & + & + \\
\hline 13 & \multicolumn{2}{|c|}{ Endospores } & + & + \\
\hline \multicolumn{4}{|c|}{ Similarity percentage (\%) } & 84,61 \\
\hline & laracters can s & w results - & or - & \\
\hline
\end{tabular}

TABLE V. THE IDENTIFICATION OF ISOLATE 31

\begin{tabular}{|c|c|c|c|c|}
\hline No & \multicolumn{2}{|c|}{ Parameters } & $\begin{array}{c}\text { Genus } \\
\text { Reference } \\
\text { (Morococcus) }\end{array}$ & $\begin{array}{c}\text { Isolate } \\
31\end{array}$ \\
\hline 1 & \multicolumn{2}{|c|}{ Gram staining } & - & - \\
\hline 2 & \multicolumn{2}{|c|}{ Cell form } & Coccus & Coccus \\
\hline 3 & \multicolumn{2}{|c|}{ Cell composition } & Paired & Paired \\
\hline 4 & \multicolumn{2}{|c|}{ Motility } & Nonmotil & Motil \\
\hline 5 & \multicolumn{2}{|c|}{ Needs of O2 } & Aerob & Aerob \\
\hline 6 & \multicolumn{2}{|c|}{ Catalase activity } & + & + \\
\hline 7 & \multirow{6}{*}{\begin{tabular}{l}
\multicolumn{1}{c}{ Acid } \\
productio \\
$\mathrm{n}$
\end{tabular}} & Glucose & + & - \\
\hline 8 & & Fructose & + & + \\
\hline 9 & & Galactose & - & + \\
\hline 10 & & Lactose & - & + \\
\hline 11 & & Maltose & + & + \\
\hline 12 & & Sucrose & + & - \\
\hline 13 & \multicolumn{2}{|c|}{ Gelaton hydrolysis } & - & - \\
\hline 14 & \multicolumn{2}{|c|}{ Nitrate reduction } & + & + \\
\hline 15 & \multicolumn{2}{|c|}{ Dissolved pigment } & - & - \\
\hline 16 & \multirow{3}{*}{$\begin{array}{l}\text { Growth } \\
\text { at various } \\
\mathrm{pH} \\
\end{array}$} & 2,5 & - & + \\
\hline 17 & & 6,1 & + & + \\
\hline 18 & & 9,6 & + & + \\
\hline 19 & \multirow{5}{*}{$\begin{array}{l}\text { Growth } \\
\text { at various } \\
\mathrm{NaCl}(\%)\end{array}$} & 0,5 & + & + \\
\hline 20 & & 0,9 & + & + \\
\hline 21 & & 5 & + & + \\
\hline 22 & & 10 & + & - \\
\hline 23 & & 25 & - & - \\
\hline 24 & \multicolumn{2}{|c|}{ Starch hydrolysis } & - & - \\
\hline 25 & \multicolumn{2}{|c|}{ Urease Activity } & - & - \\
\hline 26 & \multicolumn{2}{|c|}{ Free Nitrogen Fixation } & - & - \\
\hline \multicolumn{4}{|c|}{ Similarity Percentage (\%) } & 73,08 \\
\hline
\end{tabular}

The identification results using 13 parameters showed that isolate 26 had a resemblance to the genus Streptomyces with percentage of similarity in profile matching is $84.61 \%$. While identification results using 26 parameters showed that isolate 31 had a resemblance to the genus Morococcus with similarity percentage is $73.08 \%$. Based on the taxsospecies concept, the terms of a strain included in a group is have a similarity $>70 \%$ [12].

\section{G. Antagonists Test to Inhibit the growth of Colletotrichum} $s p$. 
TABLE VI. BACTERIA ANTAgonists Test To INHIBIT THE GROWTH OF COLLETOTRICHUM SP.

\begin{tabular}{|c|c|c|c|}
\hline $\begin{array}{l}\text { Bacteria } \\
\text { isolates }\end{array}$ & Repetition & $\begin{array}{c}\text { Inhibiting zone } \\
(\mathrm{mm})\end{array}$ & Average (mm) \\
\hline \multirow{5}{*}{ Control } & 1 & 0 & $0^{\mathrm{a}}$ \\
\hline & 2 & 0 & \\
\hline & 3 & 0 & \\
\hline & 4 & 0 & \\
\hline & 5 & 0 & \\
\hline \multirow{5}{*}{26} & 1 & 8,88 & $10,37^{\mathrm{b}}$ \\
\hline & 2 & 11,63 & \\
\hline & 3 & 11,12 & \\
\hline & 4 & 11,18 & \\
\hline & 5 & 9,02 & \\
\hline \multirow{5}{*}{31} & 1 & 10,27 & $9,46^{\mathrm{b}}$ \\
\hline & 2 & 9,72 & \\
\hline & 3 & 8,85 & \\
\hline & 4 & 9,83 & \\
\hline & 5 & 8,63 & \\
\hline
\end{tabular}

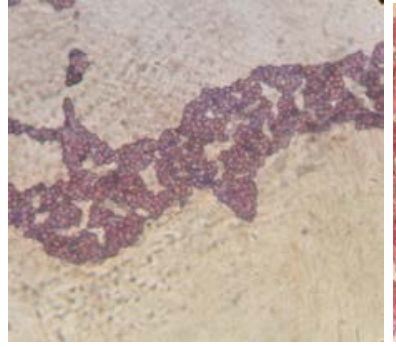

(26)

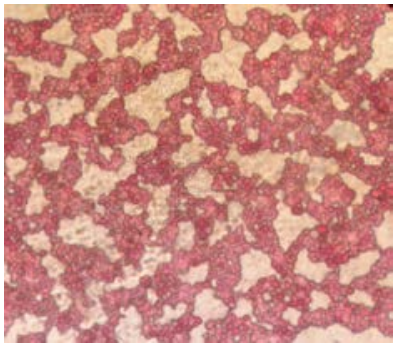

(31)
Fig. 3. Gram staining of Isolate 26 and 31

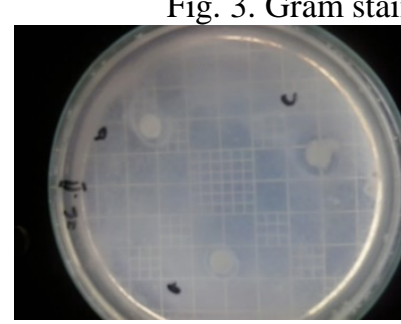

(26)

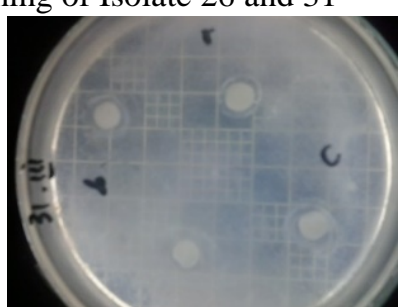

(31)
Fig. 4. Antagonist test between isolate 26 and 31 against Colletotrichum sp.

The results of comparative analysis shows that the average value of the chitinase enzyme-producing bacteria gaves a significant effect on the growth of fungus Colletotrichum sp. demonstrated by the significant value of 0.00 or $p \leq 0.05$. A significant result was then tested further using Duncan Multiple Range Test (DMRT). DMRT further test serves to compare the mean value between treatments. The results showed that there were significant differences between the treatment of isolates 26 and 31 with the control.

The real effect of bacterial isolates 26 and 31 to inhibit the growth of fungus Colletotrichum sp. compared with controls, due to the production of chitinase enzyme produced by bacteria that can inhibit the growth of fungus by breaking down the fungus cell walls.

The ability of the chitinase enzyme producing bacteria to inhibit the growth of fungus Colletotrichum sp., is a form of antagonistic bacteria against fungus [13]. The chitinase enzyme can be used in biological control of fungus plant pathogenic because the fungus cell walls contain chitin which is a chitinase enzyme substrate [14].

The mechanism of chitin degradation in the cell walls of fungus can occur in two paths, the first is degraded by chitinolytic mechanism that hydrolyzes $\beta$-1,4-glycoside. While the second mechanism is experiencing deacetylation of chitin polymer first then hydrolysed by chitosanase. Most of the soil and water microorganisms are good to degrade chitin and some microorganisms can utilize chitin as a source of carbon and nitrogen.

\section{CONCLUSION}

4.1. There are two isolates of chitinase enzyme producing bacteria that have a high enzyme activity that can be isolated from bat guano, which is isolates 26 and 31 with a chitinase enzyme activity of $1.13 \mathrm{U} / \mathrm{ml}$ and $0.98 \mathrm{U} / \mathrm{ml}$.

4.2. The amount of chitinase enzyme activity of isolate 26 in the phase lag is $0 \mathrm{u} / \mathrm{ml}$, the exponential phase is $0.30 \mathrm{u} / \mathrm{ml}$ and the stationary phase is $1.46 \mathrm{u} / \mathrm{ml}$. As for the 31 isolates had the enzyme activity in the phase lag is $0 \mathrm{u} / \mathrm{ml}$, the exponential phase is $0.16 \mathrm{u} / \mathrm{ml}$ and the stationary phase is $0.46 \mathrm{u} / \mathrm{ml}$.

4.3. chitinase enzyme-producing bacteria that have the highest enzyme activity is thought to be the Streptomyces genus for isolates 26 and genus Morococcus for isolates 31. The percentage of the reference profile matching with a genus is $84.61 \%$ for isolates 26 and $73.08 \%$ for isolates 31 .

4.4 chitinase enzyme producing bacteria Isolates from bat guano give a significant effect in suppressing the growth of fungus Colletotrichum sp, with a significance value of 0.00 or $(\mathrm{p} \leq 0.05)$

\section{REFERENCES}

[1] Wu et. al (2001) in Hanif, Andini., Dwi Suryanto., Isnaini Nurwahyuni (2014). Utilization Chitinolitic Bacteria To Inhibit the growth of Curvularia sp. Causing Leaf Spot Disease in Cucumbers. Essay. Medan: Universitas Sumatera Utara.

[2] Donderski and Brzezinska (2001) in Novitasari, Prima (2013). Isolation and Identification Chitinolitic Bacteria to Inhibit the Growth of Pathogen Fungus from Cricula trifenestrat Cocoon. Bogor: Institut Pertanian Bogor.

[3] Kaya, Murat., Osman Seyyar., Talat Baran \& Tuncay Turkes (2014). Bat Guano As New And Attractive Chitin And Chitosan Source. Available: http://www.frontiersinzoology.com/content/11/1/59 http://dx.doi.org/10.1186/s12983-014-0059-8

[4] Suryaningsih et al., (1996) in Syukur, Muhamad, et al (2009). The Resistance to Antrachnose cause by Colletotrichu acutatum Insome Genotipes Of Chilli (Capsicum Annuum L.) And Its Correlation With The Contains Of Capsaicin And Peroksidase. J. Agron. Indonesia 37 (3) : $233-239$

[5] Kefialew and Ayalew (2008) in Kusumawardhany, Dessy. (2013). Chitosan Potency, Yeast, Actinomycets and The Combination to Inhibit Antrachnose (Colletotrichum gloeosporioides (Penz.) Sacc.) in Crystal Guava Fruits. Essay. Bogor: Institut Pertanian Bogor.

[6] Janisiewicz and Korsten (2002) in Kusumawardhany, Dessy. (2013). Chitosan Potency, Yeast, Actinomycets and The Combination to Inhibit Antrachnose (Colletotrichum gloeosporioides (Penz.) Sacc.) in Crystal Guava Fruits. Essay. Bogor: Institut Pertanian Bogor.

[7] Ferniah et al (2003) in Hanif, Andini., Dwi Suryanto., Isnaini Nurwahyuni (2014). Utilization Chitinolitic Bacteria To Inhibit the growth of Curvularia sp. Causing Leaf Spot Disease in Cucumbers. Essay. Medan: Universitas Sumatera Utara.

[8] Harini \& Septariningrum (2006) in Apriani, Lisda (2008). Chitinolitic Bacteria Selection. Jakarta: Universitas Indonesia 
[9] Borda, Daniela R, et al. (2013). Aerosolized Microbes From Organic Rich Materials: Case Study Of Bat Guano From Caves In Romania. Journal of Cave and Karst Studies, v. 76, no. 2, p. 114-119. http://dx.doi.org/10.4311/2013MB0116

[10] Sandra Pratiwi, Rachmawati, et al. (2015). Chitinase Enzyme and Its Application in Industrial Sectors. Jurnal Pangan dan Agroindustri Vol. 3 No. 3 p.878-887

[11] Whitaker, John O, et al (2004). Chitinase in Insectivorous Bats. Journal of Mammalogy, 85(1):15-18 http://dx.doi.org/10.1644/1545-1542(2004)085<0015:CIIB>2.0.CO;2

[12] Goodfellow, M \& A.G. O’Donnell (1993). Handbook of New Bacterial Systematics. Academ Press, Inc.

[13] Kusnadi, et al (2003). Microbiology. Universitas Pendidikan Indonesia: JICA- IMSTEP

[14] Natsir, Hasnah, et al (2012). Production and Chitinase Application from B. licheniformis HSA3-1a to Hydrolize Chitin from Shrimps Waste and Fungus Cell Wall (Ganoderma sp). Essay. Makassar: Universitas Hasanudin. 